Отримано: 17 серпня 2019 року

Прорецензовано: 16 вересня 2019 року

Прийнято до друку: 23 вересня 2019 року

e-mail:irenas7217@gmail.com

oksananychko@gmail.com

DOI: $10.25264 / 2519-2558-2019-7(75)-31-36$
Stetsko I. I., Nychko O.Ya. Case-based instruction as a teaching method of Business English. Наукові записки Начіонального університету «Острозька академія»: серія «Філологія». Острог: Вид-во НаУОА, 2019. Вип. 7(75), жовтень. С. 31-36.

УДК $378.147+811.111(07)$

\author{
Iryna Stetsko, \\ Associate professor, PhD in Pedagogics \\ Ternopil National Economic University \\ Oksana Nychko, \\ Associate professor, PhD in Philology \\ Ternopil National Economic University
}

\title{
CASE-BASED INSTRUCTION AS A TEACHING METHOD OF BUSINESS ENGLISH
}

The article deals with the problem of using active methods of teaching Business English on the example of case study. It also highlights the definition, purpose of case study method and identifies its main functions. Besides, it focuses on basic peculiarities of case-based method for teaching English and describes the effective ways of case studies usage. Moreover, it is stated that case studies present realistic, complex, and contextually rich situations and often involve a dilemma, conflict, or problem that one or more of the characters in the case must negotiate. This method increases student proficiency with written and oral communication, as well as collaboration and team work. The peculiarity of this method of teaching is that it develops practical and cultural thinking and also develops professional and managerial skills.

In the article some of the steps how to lead a case-based discussion are pointed out: giving students time to read and think about the case; introducing the case briefly and providing some guidelines for how to approach it; creating groups and monitoring them; asking questions for clarification and moving discussion to another level; synthesizing issues raised.

Some examples of the use of case-study method at the English lessons in a professional environment (Business English, English for managers, English for economists, English for professionals in the field of advertising, for specialists in public relations) are illustrated and thoroughly analysed. The course-books "The Business" (The Pre-intermediate, The Intermediate, The Upper Intermediate, The Advanced levels) laid the foundations of the analytical analysis of the case-study method samples.

Key words: case study, case-based instruction, case-based discussion, group work, Business English, assessment, managerial skills, professional skills, counselling skills, interactive method.

Стецько Ірина Іванівна,

кандидат педагогічних наук, дочент кафедри іноземних мов

Тернопільського начіонального економічного університету

Ничко Оксана Яромирівна,

кандидат філологічних наук, дочент кафедри іноземних мов

Тернопільського національного економічного університету

\section{СASE STUDY МЕТОД У ПРОЦЕСІ НАВЧАННЯ ДІЛОВОЇ АНГЛІЙСЬКОЇ МОВИ}

У дослідженні подано дефініиію метода саsе study, визначено мету та його основні функиії. Зосереджено увагу на особливостях використання саse study метода у прочесі навчання англійської мови та схарактеризовано ефективні способи його впровадження у навчальний процес. У статті вказано поетапні кроки ведення дискусії на основі даного методу. Проілюстровано та проаналізовано окремі приклади використання саse-study метода на уроках англійської мови у професійному середовищі (Ділова англійська, Англійська для менеджерів, Англійська для економістів, Англійська для професіоналів у сфері реклами тошо) на основі аналізу навчально-методичної літератури. Обтрунтовано дочільність використання означеного метода у навчальному процесі вищої иколи.

Ключові слова: case study метод, професійні навички, управлінські та організачійні навички, Ділова англійська мова, оцінювання, робота у групах, інтерактивний метод.

Introduction. Teaching and learning styles are, by their very nature, changing and in recent years there has been a noticeable move from lecture-based activities towards more student-centred activities. Case studies are an increasingly popular form of teaching and have an important role in developing skills and knowledge in students. This approach is one of the ways in which such active learning strategies can be implemented in educational establishments.

Theoretical background. Thus, case study method is a powerful student-centered teaching strategy that can impart students with critical thinking, communication and interpersonal skills. Furthermore, case studies are, by their nature, multidisciplinary, and allow the application of theoretical concepts (Davis and Wilcock). They present realistic, complex, and contextually rich situations and often involve a dilemma, conflict, or problem that one or more of the characters in the case must negotiate. So, while working on cases students research and evaluate multiple sources of data.

Case method is also effective at developing real world, professional skills. Among the reasons for the case method's popularity is its capacity to bring the realities of the business world into the classroom through the active involvement of the student in meaningful, practice-oriented learning activities. Working on case studies requires good organizational and time management skills. This method increases student proficiency with written and oral communication, as well as collaboration and team work. Moreover, case studies force students into real-life situations, training them in managerial skills such as holding a meeting, negotiating a contract, giving a presentation, etc. (Daly, 2002).

Through case analysis, the purpose is to train students to use the following higher-order thinking skills (Emory, 2016):

- analyzing, interpreting and assessing data and situations; 
- diagnosing problems and assessing situations;

- forecasting future performance and resources in need;

- planning and goal setting;

- communicating;

- implementing and monitoring plans [12].

As a method for teaching English, case studies combine many of the latest techniques currently advocated by researchers and practitioners in the profession. They teach language through content, rather than through grammatical or lexical exercises. Content material is business-related, and thus of greater relevance and interest to the student in a business language course than nonbusiness subject matter. Case studies are typically authentic materials which present the students with actual business problems to analyze and solve, in contrast with more traditional materials that consist of dialogues [3].

Studies have shown that working in groups during completion of case studies significantly improves student perceptions of learning and may increase performance on assessment questions [7].

According to Davis (1993), an effective case study is one that:

- tells a "real" and engaging story;

- raises a thought-provoking issue;

- has elements of conflict;

- promotes empathy with the central characters;

- lacks an obvious or clear-cut right answer;

- encourages students to think and take a position;

- portrays actors in moments of decision;

- provides plenty of data about character, location, context, actions;

- is relatively concise [4].

Results and discussion. The usage of case studies will definitely depend on the goals, as well as on the format, of the course. During the lecture course, for example, one might use a case study to illustrate and enrich the lecture material. Also in a large class one might consider breaking the class into small groups or pairs to discuss a relevant case. If the class is smaller, one will be able to use more detailed and complex cases in a discussion-format course, to explore the perspectives introduced in the case in greater depth, and perhaps integrate other instructional strategies, such as role playing or debate.

Regardless of the format in which one can use case studies, it is important that the instructor know all the issues involved in the case, prepare questions and prompts in advance to enhance the discussion, and anticipate where students might run into problems.

Although, there are many effective ways of case studies usage, we would like to point out some of the steps how to lead a casebased discussion:

1. Give students time to read and think about the case. Moreover, if the case is long,give it as homeassignment with a set of questions for students to consider;

2. Introduce the case briefly, provide some guidelines for how to approach it and clarify how you want students to think about the case;

3. Create groups and monitor them to make sure everyone is involved. Breaking the full class into smaller groups gives individual students more opportunities for participation and interaction;

4. Have groups present their solutions/reasoning;

5. Ask questions for clarification and to move discussion to another level;

6. Synthesize issues raised.

Case - based instruction provides students with indispensable information about an issue, matter or problem to be solved coupled with background information. Typically ESP class engages six stages of case studies with involvement of both serious mental and linguistic competence. They are:

- reading the case;

- identifying the problem;

- defining priorities and limitations;

- looking for alternative solutions;

- choosing the best alternative and the best linguistic way to represent it;

- preparing an action plan [1, pp. 553-566].

The use of case-study method at the English lessons in a professional environment (Business English, English for managers, English for economists, English for professionals in the field of advertising, for specialists in public relations) pursue two objectives as to further improve both linguistic and socio-cultural competence and the formation of professional skills of students [13].

Foreign language activity is carried out in the following sequence: case information discussion, important information identification, exchanging of ideas on the problem stated, solution development on the given problem, final decision discussion, report preparation. In the chart below we can see some case study examples at various stages of Business English studying:

\section{BUSINESS (CLOSED) CASE STUDY: SCOTAIR}

Length: 2 hours

Level: $1^{\text {st }}$ year International Business and Management course, pre-intermediate ESP class)

Aim: To illustrate the importance of given reading and listening materials for a particular situation. To encourage students to use and analyse knowledge obtained from an audio/video demonstration

Key skills: Group work, individual study, time management

Assessment: Question sheet rate (on important things when flying), reading for gist handout, note-taking handout, group answer

Students are assigned to groups of 3-6 to the session. Each group is presented with handout sheets and a set of questions to answer. TASK: How important are these things for you when you fly? Rate the following as A (very important), B (important), C (not important). 


$\begin{array}{ll}\checkmark & \text { Free in-flight food } \\ \checkmark & \text { Free headphones } \\ \checkmark & \text { Carbon footprint of flight } \\ \checkmark & \text { A lot of legroom }\end{array}$

$\begin{array}{ll}\checkmark & \text { Wide seats } \\ \checkmark & \text { Seatback TV } \\ \checkmark & \text { Fast check-in } \\ \checkmark & \text { Free newspapers or magazines }\end{array}$
$\checkmark$ Seat allocation
$\checkmark$ Friendly cabin crew
$\checkmark \quad$ Free in-flight drinks
$\checkmark \quad$ A clean and tidy plane

There is also some information for everyone to read (group reading). TASK: read the article to gather information about changes in passenger air travel over the last 70 years and answer the following question: What two trends does the article describe? (group answer). ESP class is also presented with listening and note-taking activity/sheet to highlight relevant facts and underline key problems. There are six speakers from different countries who say about the budget airline EvanAir company and their working/ travelling experience there.

$\begin{array}{cc}\begin{array}{c}\text { Judith, } \\ \text { cabin crew, (United } \\ \text { Kingdom) }\end{array} & \begin{array}{c}\text { Robin, } \\ \text { Airline employee, } \\ \text { (France) }\end{array} \\ \begin{array}{c}\text { Has worked } \\ \text { at EvanAir for__. }\end{array} & \begin{array}{c}\text { Worked at EvanAir } \\ \text { for three months. }\end{array} \\ \begin{array}{c}\text { EvanAir don't provide } \\ \text { tea, coffee or water. }\end{array} & \begin{array}{c}\text { Spent } \\ \text { per day and three hours } \\ \text { travelling to work. }\end{array} \\ \text { Has to pay } & \text { Often started } \\ \text { for her uniform } & \text { to work at }\end{array}$

\section{Michael, passenger, (Ireland)}

EvanAir has revolutionazed air travel.

In the past only people could fly, now everybody can afford it.

\section{Anna, passenger, (Holland)}

EvanAir are uncomfortable but also

Flying is quicker than train or car.

\section{Morten, concerned citizen, environmentalist (Norway)}

Difficult for the crew to leave and find new jobs.

Doesn't use budget airlines because safety and are more important.

Britain's CO2 emissions are increasing.

Short-haul flights are the worst because most fuel is used for __ and landing.

The process of preparing the students for solving a case is based on skills and abilities to work with information tools to update the existing knowledge, stimulate research activities. At the stage of collecting information a variety of sources are used based on modern communications: television, video, computer dictionaries, encyclopedias and databases available through the communication system. These sources provide more comprehensive and more relevant information. The next stage is information processing to classify and analyse the facts to represent the overall picture of the phenomenon or event. The final phase is representation of the reasoned decision submitted in the form of presentations, illustrated text messages, tables, graphs, charts, etc. [13]. The above-stated closed case study type implies that the students are provided with all information they need and the proposed solutions are not expected to differ considerably since all the groups have an access to the same source of information.

Leading a case discussion consists of two primary activities: questioning and listening. Although every discussion is different a standard set of steps might follow situation description, possible action definition, identification of the consequence of each action choice, "best" action selection, summarizing and generalization of the given case. The "big" questions in the discussion should move the students through this arc, but the teacher should also prepare a series of questions designed to do smaller tasks like information getting form the case, inducing students to partner work, fostering debate, pushing students to support and defend their points of view. At the initial stage of case study discussion it's indispensable to wrap up appropriately a case by highlighting and summarizing case points. It's also a good time for the instructor to get a sense of what students are taking away from the discussion. A form of ONE MINUTE PAPER in which they are asked to write down their answers to a few questions, including: "What was the main point of the case?" "What did you learn from the discussion?" "How well do you think you performed?" "What did you like or dislike about the discussion"?

\section{BUSINESS CASE STUDY: COUNSELLING}

Length: 2 hours

Level: $2^{\text {nd }}$ year International Business and Management course, intermediate ESP class)

Aim: to demonstrate the application of theoretical concepts in an item of counselling goals, skills and phases and to encourage students to study the importance of the topic independently, help them to understand and to interpret the above-stated concepts of the given problem

Key skills: Group work, presentation skills, individual graph study, written communication, time management

Assessment: Question sheet handout, counselling language sheet handout, counselling skills checklist handout, counselling graph (for gap-filling) handout, group presentation

Students are assigned to groups of 3-6 to the session. Each group is presented with handout sheets and a set of questions to answer. The students are also offered to listen to the extract from a lecture on counselling skills to complete the handout. Task: Brainstorm a list. Case synopsis: What kind of personal problems can interns or employees experience when working abroad? Listen to the extract from a lecture on counselling: Firstly, the goal of counselling is to help another person manage a personal problem using their own resources. Secondly, counselling is about listening, not about telling. It's about talking to someone and helping, not about persuading or manipulating. And counselling is about assisting and exploring problems. It's not about reassuring someone or solving their problems for them. Thirdly, the three phases of counselling. Phase one, talk. This is where you encourage the problem holder to talk about the problem and to start to understand how they feel about the problem and why they feel that way. Phase two, think. This is where you encourage them to think about the problem and reassess it. You help them to see their situation from a new perspective, so that they can consider the different options for dealing with the situation. And phase three, act. This is where you help them to choose their own solution and to establish an action plan to manage the problem. 
Counselling

Counselling = helping someone

Counselling skills

listening

manipulating

talking

helping

persuading

telling

assisting

exploring problems

reassuring

solving (for them)

THE THREE FASES OF COUNSELLING

Phase one $=$

Phase two $=$

Phase three $=$

COUNSELLING LANGUAGE

The groups are also required to match each phrase in the box to a counselling skill. They are provided with another handout given below:
How do you feel?
Why not start by - "ing..?
What's your first priority?
You were surprised?
What would happen if (+past tense)?
Right.
So, to sum up, ....
So you are saying that...?
What are the options?

\section{COUNSELLING SKILLS CHECKLIST}

\section{Counselling skill}

1.Asking open questions

2. Paraphrasing

3. Paying attention

4.Encouraging

5. Echoing

6. Summarizing

7.Establishing opinions

8.Asking hypothetical questions.

9.Prioritizing

10. Action planning

\section{Description of skill}

Ask who, why, what, where, how, etc, to get them talking about the issues. Clarify your understanding by rephrasing what they said, and feed it back to them.

Use positive body language to show that you are really listening.

Show you are interested by nodding and saying uh, huh, Mmm,

Yeah, I see, etc.

Encouraging them to tell you more about a topic by repeating a key phrase or word.

Show you have understood all they said by pulling it all together in two sentences.

Get ideas from them on positive alternatives to resolve the problem.

Encourage the problem holder to think through the implications of the suggestions.

Establish which of the possible options the problem holder chooses to tackle first.

Suggest a clear first step they can take to help them manage the problem.
Useful phrases or body language

The students are expected to find out further information by adding one or more phrase of their own to each counselling skill in the handout above. A final component to the class study is to give a 5 minute presentation with a partner to describe a situation when they helped someone with a problem or when someone helped them. TASK: Did your experience correspond to what you heard in the lecture? The students therefore have to share their personal research experience and relate the information to their acquired knowledge from the lecture they've just heard (group answer).

\section{BUSINESS (SEMI OPEN) CASE STUDY (DECISION-MAKING ASPECT): CAR -GLAZER}

Length: 3 hours (one lab session)

Level: $3^{\text {rd }}$ year International Business and Management course, upper-intermediate ESP class)

Aim: the present study aims to illustrate why given materials are used for a particular application, to apply Business and Economics English skill, to give students the opportunity to investigate and analyse the given case, to encourage learners to actively engage in learning to discuss, argue and negotiate idea and to collaboratively solve a problem in interactive learning environment, to show active participation in the problem solving and critical thinking abilities.

Key skills: Group work, presentation skills, time management

Assessment: Group holding a meeting, peer assessment

Primarily this case study requires students to work together in groups of 5-6 to assess a number of statements which tend to evaluate employer's actions towards his employees. To help the students to do the task a number of honest/dishonest statements are presented: making personal photocopies at work, using the company phone to make private calls, embezzling money from the company, going to the dentist during working hours, throwing a "sickie", surfing the net during office hours, borrowing money from the petty cash. Case summary: Following this, the study covers three documents to consider: Car-Glazer International chief accountant responsibilities, 
Car-Glazer business and its services, memo written to all technicians to reduce a growing number of claims from unsatisfied customers. Groups then assemble and are given ten minutes to brainstorm the suggested questions. This helps to highlight basic company concerns that the company faces with its technicians. The students are also asked to discuss the company organigram and its staff members. The students are expected to consider an email written by one the company's staff member dealing with acquired debts in the business. To find out further information the students are told to listen to the telephone abstract disclosing the reasons of retarded payments caused by the company Sales Manager. To tackle the problem the students are told to hold/arrange a meeting to decide what action Car-Glazer should take regarding Filip Novak- the company Sales Manager. The session with a role play exercise which requires students to act out a meeting assuming in particular the roles of Emily Wuatt (Chief Acountant), Sales Manager (Filip Novak), Area Sales Managers, Warehouse manager and HR manager, company technicians. Each group has to assess the following courses of action: reprimand, official warning, dismissal, etc. With the given above semi open type of case study the students are presented with a limited amount of information and are tasked to search for the additional background information and make both internet and personal investigation, so the case solutions that various group of students put forward will vary significantly due to the fact that each group uses different sources and report different research. The suggested type of decision-making case study provides students with a current problematic situation and the students are supposed to offer a solution of their own not having being found yet.

\section{BUSINESS MARKETING CASE STUDY: MPO FENÉ́TRE}

Length: 4 weeks (Introductory lectures and presentation sessions)

Level: $4^{\text {rd }}$ year Marketing course, advanced ESP class)

Aim: This case study is designed to illustrate the practical application of the theoretical concepts covered during marketing and strategy lectures. it enables the review of the fundamentals of market analysis, demonstrating the criteria used for strategic decisionmaking and for implementing a business strategy. Specifically, the case study focuses on marketing strategies. Working on this case study will show the student how to:analyse a company's internal and external environment; to identify the "key success factors" for a company operating in this industry; to draft a sales pitch; to decide on the size of the salesforce needed for a targeted commercial area; to calculate a selling price; to determine the feasibility of promotional offers, such as discounts

Key skills: Group work, poster presentation skills, time management, independent research, business environment analysis (SWOT, PESTEL) estimation and calculation of the operating margin, research on human resources and hiring issues

Assessment: Group reports, poster presentation, peer assessment

Case synopsis: Research problem: How to succeed in the PVC window market?

This case study is based on real events which occurred in 2010. It describes the launch by MPO Fenetres of new windows, characterised by improved thermal performance, achieved by the use of triple glazing. This company is based in the French region of Orne. It has 200 employees, and realized a turnover of over $€ 35$ million in 2010 . It has positioned itself as an innovative company, always seeking to apply the latest technical developments. In the current economic crisis customers are more careful with their money, and think more carefully about potential purchases. In recent years it has been shown that consumers' purchasing behaviour has evolved, and that criteria such as sustainable development and environmental protection are now among the factors that may influence purchasing decisions. In this sense, an "ecological consciousness" has emerged. Not only the Grenelle de l'Environnement (a French forum for the discussion of issues relating to sustainable development) and government standards, but also tax credits associated with the purchase of certain goods, have affected the housing industry, and therefore also window manufacturers. Rebuilding and renovation are also subject to these factors. In this context, the launch of windows made of PVC, with their high thermal performance and technical and competitive advantages, was important for this SME. It was the company managers' responsibility to launch and market these products successfully. Tasks: students are expected to carry out and independent research on the given case. Students address their case study objectives by handing in their individual/group report and giving a presentation. It's essential to consider: a. Pricing policies.b. Promotion.c. Product lines. d. Channels of distribution.e. Geographic concentration.f. Increases or declines in firms or profitability.

\section{Checklist for Analyzing the Current Situation of the discussed company:}

Phase 1: The environment.

1. Are there any trends in the environment that could have an effect on the industry, firm, or management program? 2. What is the state of the economy? Inflation? Stagflation? Depression? 3. What is the cultural, social, and political atmosphere?

4. Are there trends or changes in the environment that could be advantageous or

disadvantageous to the industry, firm, or management program? Can the management

program be restructured to take advantage of these trends or changes?

Phase 2: The industry.

1. What industry is the firm in? What class of industry? Are there other industries the firm is competing with? 2. What is the size of the firm relative to the industry?

3. How does the firm compare in terms of market share, sales, and profitability with the rest of the industry? 4. How does the firm compare with other firms in the industry in terms of a financial ratio analysis? 5. What is the firm's major competition? 6 . Are there any trends in terms of government control, political, or public atmosphere that could affect the industry?

Phase 3: The firm.

1. What are the objectives of the firm? Are they clearly stated? Attainable?

2. What are the strengths of the firm? Managerial expertise? Financial? Copyrights or

patents? 3. What are the constraints and weaknesses of the firm?

4. Are there any real or potential sources of dysfunctional conflict in the structure of the firm? 5 . How are the functional departments (e.g. marketing, financial services, controlling, HR...) structured in the firm? 6. What is the corporate culture of the firm? What kind of management style is preferred? How do employees communicate?

Phase 4: The management program.

1. What are the objectives of the management program? Are they clearly stated? Are they consistent with the objectives of the firm? Is the entire management toolbox structured to meet these objectives? 2. What management concepts are at issue in the 
program? Is the management program well planned and laid out? Is the program consistent with sound management principles? If the program takes exception to management principles, is there a good reason for it? 3. To what target market is the program directed? Is it well defined? Is the market large enough to be profitably served? Does the market have long-run potential? 4. What competitive advantage does the management program offer? If none, what can be done to gain a competitive advantage in the market place? 5. What products are being sold? What is the width, depth, and consistency of the firm's product lines? Does the firm need new products to fill out its product line? Should any product be deleted? What is the profitability of the various products? 6 . What promotion mix is being used? Is promotion consistent with the products and product images? What could be done to improve the promotion mix? 7. What channels of distribution are being used? Do they deliver the product at the right time and right place to meet consumer needs? Are the channels typical of those used in the industry? Could channels be made more efficient? 8 . What pricing strategies are being used? How do prices compare with similar products of other firms? How are prices determined? 9. Are business research and information systematically integrated into the management program? Is the overall management program internally consistent? 10. Are (senior/middle) managers capable to translate strategy into action? Are managers excellent in action or just in talking?

Writing reports preparation: Conduct an internal and an external diagnosis of the company. Use the SWOT tool to synthesize this information. Identify the Key Factors for Success from the diagnosis. Write a sales pitch for the company. Prepare sales claims to be presented to sellers. Remember to take into account the potential objections of customers: provide the employees with arguments to counter customers' misconceptions. Suggest incentives to stimulate the sales force (bonuses, collective or individual incentives, etc.) to encourage their continued training and to support sales of this product. Determine the optimum size of a business team for an agency, using the information provided in the case study. Consider the effectiveness of an agency's sales team and the commercial influence that the agency can exercise in its area of operation. Assess the feasibility of a commercial promotion offering "triple-glazed windows for the price of double glazing" for the product launch.

It becomes worthwhile thinking about case studies as a means of exploiting authenticity in ESP classes. Firstly, all cases studies show a considerable level of text authenticity [1]. The primary aim of case studies is to provide students of economics and business with actual, real information in contrast with more traditional materials and texts consisting of dialogues, or reading sections related to business and economic topic. Secondly, case studies perfectly fit into the task authenticity. ESP case studies prevent students from responding mechanically to a limited number of situations and engage them into more complex activities such as problemsolving or decision-making ones. The teaching method of case studies also promotes learner authenticity. Being engaged in such a communicative activity, students develop positive feelings and responses towards the studied material. While solving business cases students tend to share certain psychological states as: worries, concerns and suspicions that a native speaker would normally feel in a similar problem-solving situation. Finally, case studies bring about classroom authenticity. The classroom plays a pivotal role in creating a real-like world within its walls, making a unique learning environment resulted in various interactions.

Conclusion. Case studies as an ESP teaching and learning method equip students with both analytical and problem-solving skills. They are of particular importance for improving managerial and project coordination skills. While being tasked with a particular case students are expected to collect information, analyse data and then report their findings. This requires critical thinking, pondering upon the supplied text, contemplating about positive solutions and putting forward feasible business solutions. Case discussions trigger the learner to learn independently, honing one's skills for self-directed learning experience. By learning to do this students grow as future businessmen with business skills and dexterities, learn to grow and become proactive in a dynamic environment. Case studies foster negotiating and chairing skills as well. Students not only participate in a linguistic in-class activity, but constitute a part of a business culture and business ethics. While analysing case studies students pay special attention to the intricacies of a specific culture and learn how to behave within various ethic contexts. At the same time their professional vocabulary is enriched and practically employed giving the meaning to the whole learning process. Case - based teaching is an interactive method to enable learners to learn through real-life scenarios and settings.

\section{Bibliography:}

1. Basta Jelena. Role of case studies in teaching English. THE JOURNAL OF TEACHING ENGLISH FOR SPECIFIC AND ACADEMIC PURPOSES. Vol. 5, No 3, 2017, pp. 553-556).

2. Barkley, E. F, Cross, K. P. \& Major, C. H. (2005) Collaborative Learning Techniques: A Handbook for College Faculty. SanFrancisco: Jossey-Bass. 448 p.

3. Christine Uber Grosse. The Case Study Approach to Teaching Business English. EngIish for Specific Purposes. Vol. 7. pp. 131136. 1988. Pergamon Press Plc. Prmted in the USA. Copyright/ 1988 The American University/ https://www.sciencedirect.com/sdfe/pdf/ download/eid/1-s2.0- 0889490688900312/first-page-pdf

4. Davis, B. G. (1993). Tools for Teaching. Jossey-Bass Inc., San Francisco: California. 429 p. URL: https://www.indiana.edu/ istr695/ readingsfall2013/Tools\%20For\%20Teaching.pdf

5. Davis, C. \& Wilcock, E. Teaching materials using case studies. UK Centre for Materials Education, Higher Education Academy. URL: http://www.materials.ac.uk/guides/casestudies.asp

6. Emmerson Paul, John Alilison, Jeremy Townend. “The Business Advanced”, Macmillan Education, 2008. 160 p.

7. Flynn, A. E., \& Klein, J. D. (2001). The influence of discussion groups in a case-based learning environment. Educational Technology Research and Development, 49(3), 71-86. URL: http://dx.doi.org/10.1007/BF02504916

8. John Allison, Paul Emmerson. "The Business Intermediate Student's book", Macmillan Education, LTD, 2012. $157 \mathrm{p}$.

9. John Allison, Jeremy Townend, Paul Emmerson. "The Business Upper-Intermediate Student's Book", Macmillan Education, LTD, 2012. $150 \mathrm{p}$

10. Molise Habasisa. Using Case study as a Teaching and Learning strategy in the Teaching of Economics: A Literarure Review. Mediterranian Journal of Social Sciences. MCSER Publishing, Rome, Italy:Vol 5, No 23, November 2014.

11. Richardson Karen, Kavanagh Marie, Sydes John, Emerson Paul. "The Business pre-intermediate Student's Book", Macmillan Education, LTD, 2012. $160 \mathrm{p}$.

12. Wenhua Hsu. Case Method to Teaching English for Business Communication. Education and Linguistics Research. ISSN 23771356 2016, Vol. 2, No. 2. URL: https://pdfs.semanticscholar.org/eaa9/f4d77b1b0c28d6c6117eb9e39dc74b148b03.pdf

13. Солиева M. A. Case-study method in teaching English for Specific Purposes [Текст]. Проблемы и перспективы развития образования: материаль VIII Междунар. науч. конф. (е. Краснодар, февраль 2016 г.). Краснодар: Новация, 2016. C. 19-22. URL https:// moluch.ru/conf/ped/archive/187/9601. 